\title{
Runoff Estimation of Watershed in Hemavathy Basin using GIS based SCS-CN Method
}

\author{
K. Balakrishna* and H.B. Balakrishna \\ Department of Civil Engineering, Bangalore Institute of Technology Bangalore-560004, Karnataka, India
}

Received 15 March 2019, Accepted 17 May 2019, Available online 20 May 2019, Vol.9, No.3 (May/June 2019)

\begin{abstract}
Estimation and quantification of catchment surface runoff an important hydrologic variable used in most of the water resources applications watershed development and management problems. In this study, rainfall-runoff relationship of Hemavathy river basin is determined using Soil Conservation Services-Curve Number (SCS-CN) method for runoff estimation for ungauged watersheds. The important parameters considered include land use/land cover, soil, vegetation, drainage, precipitation, contour, slope, daily rainfall data. From the 11 year daily rainfall data daily runoff was estimated using SCS CN equation considering antecedent moisture conditions. Daily runoff depth in the watershed was then computed using SCS-CN equation was later converted to runoff volume. It was observed in runoff potential of the watershed about $41 \%$ of area having high CN value interprets in more runoff. The runoff thus calculated was compared with gauged flow at dam site observed that regression coefficient is almost same for both estimated and observed data and an increase of about 15\% in inflow data as per project authorities in the catchment which may be due to regenerated water from irrigation and presences of perennial streams in the catchment even during non-monsoon months there is inflow observed.
\end{abstract}

Keywords: Antecedent Moisture Condition, Curve Number, GIS, Hydrologic Soil Group, SCS-CN, Surface Runoff.

\section{Introduction}

With the growing human population water demand for agriculture, domestic, industrial and other uses increased resulted in over-exploitation of water sources leading to declining water table levels. Rainfall patterns in the area are untimely and unpredictable, efficiently harvesting the rainwater is important to meet them, in sustainable manner by increasing water availability and recharging the water table in the process. The volume and rate of runoff depends on precipitation, watershed characteristics, soil type, land use and antecedent soil moisture. For efficient design, planning and management of river basin estimation of runoff magnitude is necessary. The remote sensing in runoff estimation provide an aid for estimating equation coefficients and model parameters. This research aimed at estimating the annual rainfall- runoff potential of Hemavathy river watershed by applying SCS-CN model with ArcGIS 10.1 software. This method includes several important properties of watershed namely soil permeability, land use and antecedent soil moisture condition (Ashish Pandey et al, 2004). Accurate assessment of run-off is a basic concept in most of the rainfall-runoff models, the run-off

*Corresponding author is a Research Scholar (ORCID ID: 0000-00029685-1787) and Dr H.B. Balakrishna is working as Professor DOI: https://doi.org/10.14741/ijcet/v.9.3.10 measurements by gauging can only be regarded as an index of rainfall, to overcome some of these problems, remote sensing satellite data are of immense use (Dilip.G et al, 2001).Curve number model is more suitable for ungauged runoff in agricultural watersheds compared with other watersheds (Mishra, S. K et al, 2006).The combinations of SCS-CN model with Remote sensing and GIS help in the process of runoff estimation in efficient manner (Patil J.P et al, 2008).Understanding the distribution of precipitation in the hydrological cycle into runoff, evapotranspiration, infiltration is necessary for proper management and development strategy for efficient utilization of water resources generated. When it is desired to use water at rate in excess of the available discharge in the stream water stored in suitable locations during the period of high flow can be utilized during the period of low flows to maintain uniform flow as required.

\section{Study area}

The area selected for present study was Hemavathy catchment situated in Chickamaglur Hassan and Kodagu district lies geographically between $75^{\circ} 30^{\prime} 0^{\prime \prime}$ and $76^{\circ} 15^{\prime} 0^{\prime \prime}$ E longitude and $12^{\circ} 30^{\prime} 0^{\prime \prime}$ and $13^{\circ} 30^{\prime} 0^{\prime \prime} \mathrm{N}$ latitude. It covers an area of 2855 Sq.km and shows a relief of $0.760 \mathrm{~km}$. The length and width of the catchment is $74.057 \mathrm{~km}$ and $63.413 \mathrm{~km}$ respectively. 


\section{Data and Methodology}

A common base map was prepared using SOI Topo sheets which serve as control points in interpretation of remotely sensed data. Drainage map for the area was prepared using SOI Topo maps updated with recent remote sensed data and each stream assigned an order .Daily rainfall data for eleven years(2005-2015) was collected from Karnataka State Natural Disaster Monitoring Centre, Bangalore, IRS-P6 LISS III satellite data was used to prepare the landuse/landcover, soil and drainage maps. soil map was classified into four hydrological soil groups, ArcGIS used to process carto sat DEM(digital elevation model) to describe drainage patterns of watershed. DEM is used to generate slope map that gives contour interval of $10 \mathrm{~m}$. The mean rainfall for the area was determined by means of theissen polygon method. Average yearly values of rainfall are shown in Table1.Figure.1 shows the Thiessen polygon map for Hemavathy catchment. Mean rainfall was calculated for the catchment using Thiessen polygon method which is tabulated in Table 2

Table 1 Mean rainfall for the catchment

\begin{tabular}{|c|c|c|c|c|c|c|c|c|c|c|c|c|c|c|c|}
\hline Year & 2001 & 2002 & 2003 & 2004 & 2005 & 2006 & 2007 & 2008 & 2009 & 2010 & 2011 & 2012 & 2013 & 2014 & 2015 \\
\hline $\begin{array}{c}\text { Average } \\
\text { annual } \\
\text { rainfall } \\
(\mathrm{mm})\end{array}$ & 1443 & 1146 & 1003 & 1554 & 1875 & 1906 & 2176 & 1839 & 1874 & 1818 & 1748 & 1313 & 1913 & 1801 & 1513 \\
\hline
\end{tabular}

Table 2 Thiessen weights for the catchment

\begin{tabular}{|c|c|c|c|}
\hline Sl No & Station Name & Area of Thiessen polygon (Sq.km) & Thiessen Weights \\
\hline 1 & Hallibailu & 124.68 & 0.043 \\
\hline 2 & Mallipatna & 104.46 & 0.036 \\
\hline 3 & Dudda & 2.74 & 0.001 \\
\hline 4 & Hagare & 139.44 & 0.048 \\
\hline 5 & Bilur & 181.43 & 0.062 \\
\hline 6 & Attigundi & 14.41 & 0.005 \\
\hline 7 & Kalasapura & 16.55 & 0.006 \\
\hline 8 & Sanivar Santhe & 110.08 & 0.038 \\
\hline 9 & Kodlipet & 107.13 & 0.037 \\
\hline 10 & Somwarpet & 56.03 & 0.019 \\
\hline 11 & Kundooru & 153.42 & 0.053 \\
\hline 12 & Shukravar Santhe & 109.49 & 0.038 \\
\hline 13 & Gorur & 74.19 & 0.025 \\
\hline 14 & Hassan & 171.44 & 0.059 \\
\hline 15 & Belur & 168.76 & 0.058 \\
\hline 16 & Belagodu & 171.34 & 0.059 \\
\hline 17 & Arehalli & 158.29 & 0.054 \\
\hline 18 & Alur $(\mathrm{H})$ & 182.20 & 0.063 \\
\hline 19 & Gendehalli & 142.06 & 0.049 \\
\hline 20 & Sakaleshpur & 89.77 & 0.031 \\
\hline 21 & Hanbal & 123.45 & 0.042 \\
\hline 22 & Javali & 33.26 & 0.011 \\
\hline 23 & Gonibeedu & 137.74 & 0.047 \\
\hline 24 & Malalur & 104.85 & 0.036 \\
\hline 25 & Chikkamagalur & 133.63 & 0.046 \\
\hline 26 & Aldur & 99.11 & 0.034 \\
\hline
\end{tabular}




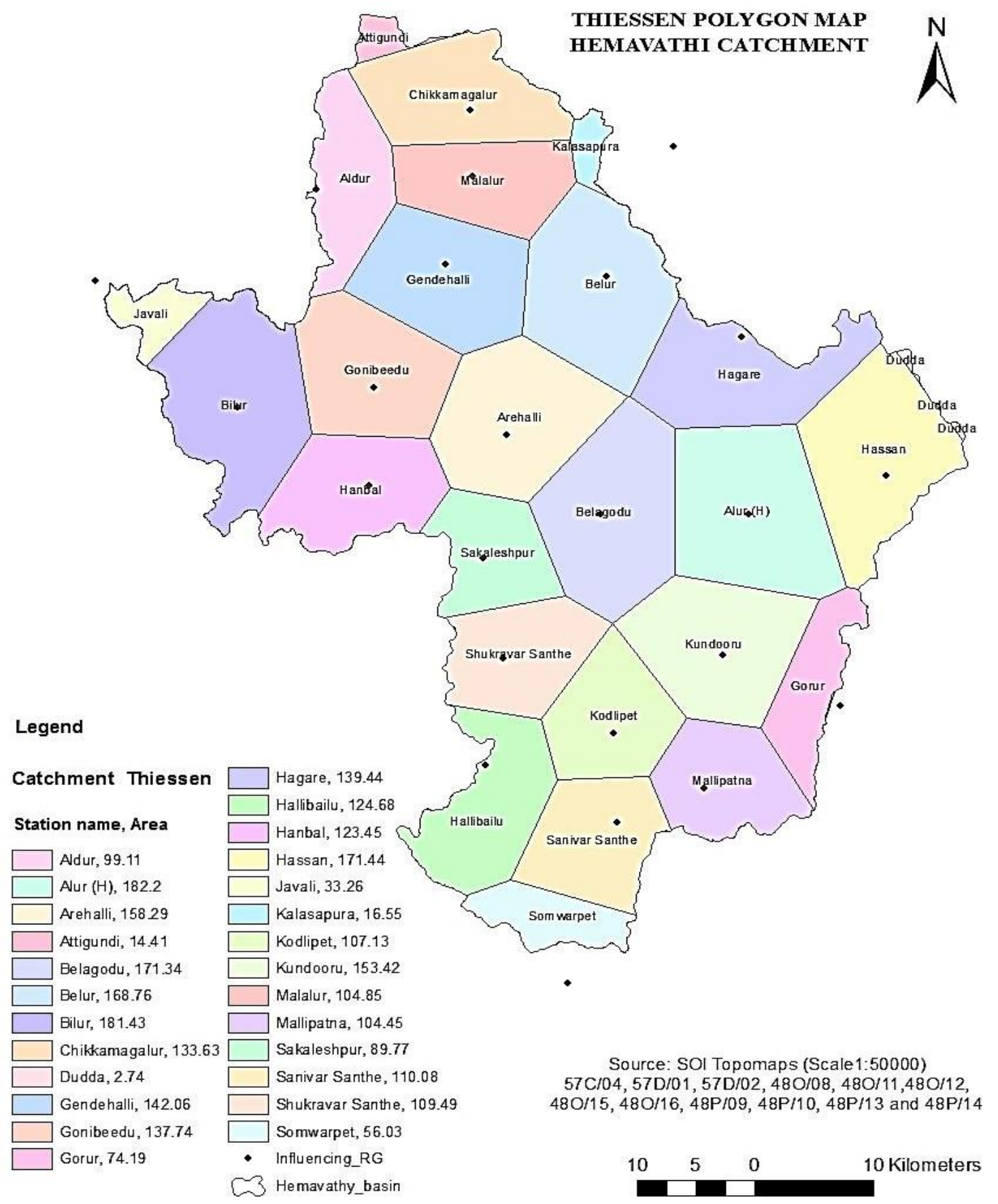

Figure.1 Thiessen polygon map for Hemavathy catchment

\subsection{Estimation of runoff}

The SCS curve number method of runoff estimation of the river basin is based on the water balance equation and two fundamental hypotheses. Runoff estimation of the watershed is estimated sub watershed wise by dividing the basin area into 26 sub watersheds. Quantity of runoff is assessed after deducting initial abstraction retention, storage from the volume of precipitation Ratio of the actual direct runoff to potential runoff is expressed as;

$\frac{Q}{P-I_{a}}=\frac{F}{S}$ where $Q$ is the actual runoff, $P$ is the rainfall and $F$ is the actual infiltration, $I_{a, \text { is }}$ the initial abstraction, $S$ is the potential infiltration after the runoff begins $(S>F)$. $F=\left(P-I_{a}\right)-Q$, Runoff $\mathrm{Q}$ is calculated as

$Q=\frac{\left(P-I_{a}\right)^{2}}{\left(P-I_{a}\right)+S}$

The units of $\mathrm{P}, \mathrm{Q}$,Ia, $\mathrm{F}$ are represented by mass curve which shows the Relation of $Q$ versus $P$. Figure 2 shows relationship between precipitation, runoff and retention, Figure 3 shows Mass curve representation of the SCS rainfall runoff relationship. 


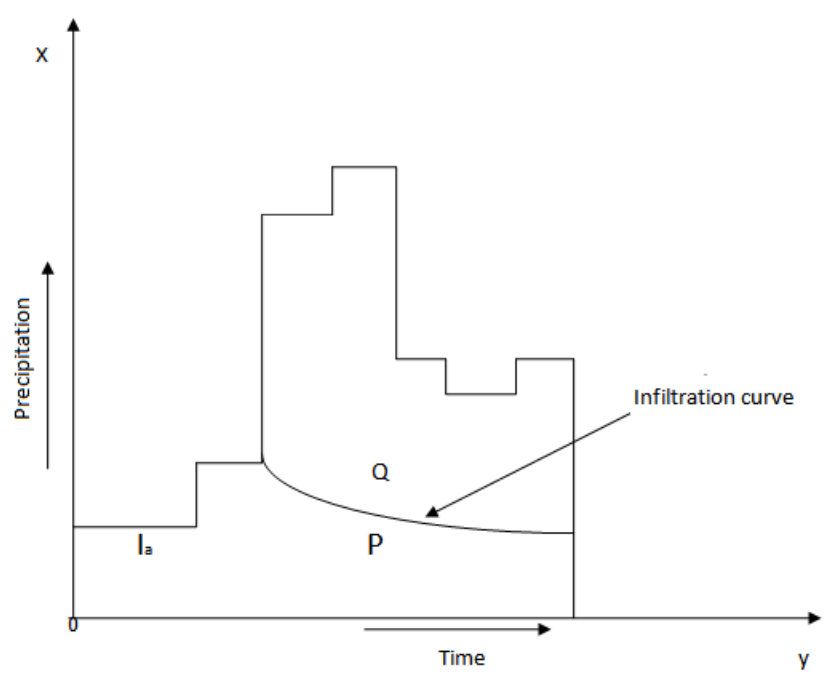

Fig.2 Relationship between precipitation, runoff \& retention

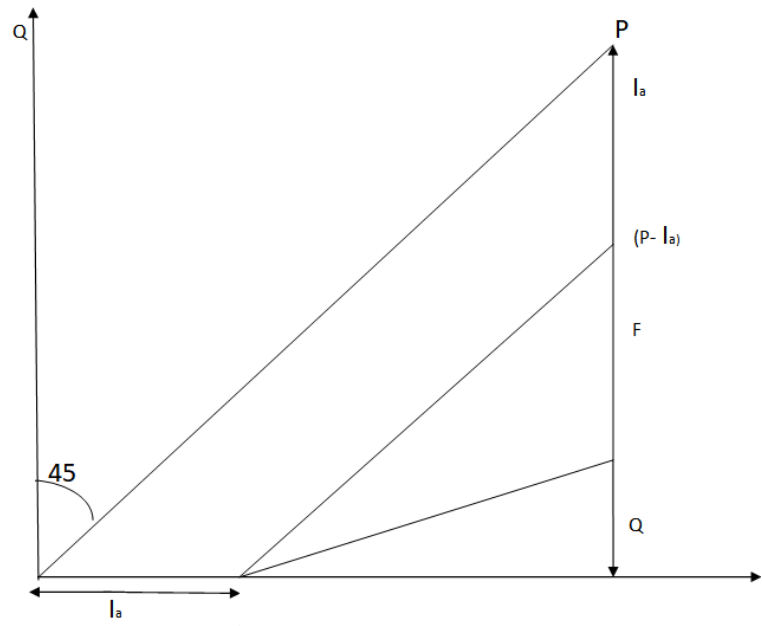

Fig 3 Mass curve representation of the SCS rainfall run off relationship

\section{References}

Ashish Pandey and Dabral P.P (2004), Estimation of Runoff for Hilly Catchment using Satellite data, Journal of Indian Remote sensing,Vol.32, pp. 235-240.

Dilip.G, Durbude, Purandara.B. K and Arun Sharma (2001), Estimation of Surface Runoff Potential of Watershed in Semi-arid Environment- A Case Study, J. Indian Soc. Remote Sensing, Vol. 29, pp. 47-58

Mishra, S. K, Jain, M. K, and Singh, V. P (2006) Evaluation of AMC-Dependent SCS-CN-Based Models Using Watershed Characteristics, J. Water Resources Management 20 pp. 531-552
Patil J.P, Sarangi A, Singh O.P, Singh A.K, Ahmad T, (2008), Development of a GIS Interface for Estimation of Runoff from Watersheds, Journal of Water Resource Management, Vol. 22, pp. 1221-1239.

Jasrotia A. S, Dhiman S. D, Aggarwal S. P, Rainfall - Runoff and Soil Erosion modeling using Remote Sensing and GIS Technique - A case study of Tons watershed, Journal of Indian Society of Remote Sensing, Vol. 30, No. 3, pp. 168180.

Ravikumar, A. S, (2001), Water Balance Components from Field Studies Using Remote Sensing and Geographical Information System, Ph. D Thesis, Indian Institute of Science, Bangalore. 